\title{
JURIDICAL ACTIVITY AS A SPECIAL AREA FOR THE APPLICATION OF JURIDICAL ALGORITHMS
}

Manko D. G.

\section{INTRODUCTION}

Juridical activity is a special type of social practice. It is related to such principles as legal education, analytical thinking, knowledge of current legislation, understanding of procedural and processual features of legal proceedings.

The effectiveness of such activity is based on the knowledge of the conditions of establishing the factual circumstances of the case and their proper registration, high legal qualification and the ability of legal construction, taking into account the understanding of the rules, methods, and principles of technologies for solving a legal case and the creation of legal acts.

There is no doubt that juridical activity is a special kind of legal activity. The legal activity of legal entities is manifested in the form of legally significant actions (acts or inactions).

Taking into account the fact that a system of specially authorized bodies and, accordingly, targeted logistic is necessary for the implementation of the juridical activity, the main form of such activity is the legal process. It is the main form, though not the only one since separate procedures are also carried out within the framework of juridical activity.

Legal procedure, for its part, is a form of implementation of legally significant actions (which are primarily one-off). Report submission, signing of the contract and many other legal procedures do not require "special" powers, the system of special bodies, and accordingly the logistical support from the subject of their implementation.

However, the correlation of categories of juridical activity and legally significant actions indicate a wider scope of the latter's logical content. Juridical activity is a specific form of legal action carried out by specially authorized entities.

\section{Juridical activity in the system of social activities}

In his turn, V.I. Chervonyuk states that "legal activity is a social quality that stems from social and legal principles, needs and interests of people, and is characterized by the actual implementation of legal requirements, principles, and regulations. Legal activity characterizes the life of law at the stage when its prescriptions and principles become effective. Therefore, 
simplifying, we can say that law in action tends to legal activity, the content of which is any manifestation of law in public life. Legal activity thereby reflects the interaction between society and the individual that is provided by the law. Consequently, the content of legal activity covers: 1) a set of personal social and legal qualities of the subjects which determine the possibility of their participation in the legal life (internal aspect); 2) the very real life of the individual, the community of people in its various quantitative and qualitative characteristics in the scope of law (external aspect) ${ }^{1}$.

According to I.M. Zaitsev, "juridical activity is characterized by a certain order, which must be - and in most cases is - optimal for the implementation of certain legally significant actions. It is established by the relevant regulations. For instance, the rules and regulations of representative bodies of state power, the adoption of legislative acts, the elections, the defense of dissertations, the procedure for service of a housing warrant, inheritance, etc. The optimum order contains a program of juridical activity, it is of indicative importance for the achievement of a particular legal goal, thereby increasing the efficiency of legal regulation of juridical activity and guaranteeing its legitimacy and effectiveness.Violation of the order is an offence, and in some cases, the results of such unlawful activities are legally void (invalid)"2.

However, legally significant actions can be implemented in the form of inaction. So, for example, compliance with the provisions of regulations that prohibit certain actions.

Therefore, it should be taken into consideration that the legally significant activity of legal entities can be manifested: 1) in the form of juridical activity (carried out in the form of legal process and legal procedures), 2) in the form of performing separate legal actions (carried out in the form of legal procedures), 3) in the form of legally significant inaction a) is carried out in the form of a legal algorithm for compliance with the prohibition, b) is carried out in the form of awareness of a legally significant prescription (understanding of norms-definitions, notions, regulations, principles).

Juridical activity is a reflection of the features of law-making and implementation of legal norms that are carried out in accordance with established rules, as well as: legal culture, legal technology and legal education in a particular country. This necessitates an analysis of the legal system in more detail and the separation of its constituent elements.

\footnotetext{
1 Элементарные начала общей теории права: учеб. пособие для вузов / под общей ред. д-ра юрид. наук, проф. В. И. Червонюка. Право и закон, М.: Колос С, 2003. С. 54.

2 Зайцев И. М. Понятие и содержание юридического процесса // Теория государства и права. Курс лекций. Под ред Матузова Н. И., Малько А. В. 2-е изд., перераб. и доп. - М.: Юристь, 2001. С. 442.
} 
According to N.M. Onishchenko, the structure of the legal system includes the following principal elements: "1) law as a set of norms created and protected by the state; 2) legislation as a form of expression of these norms (regulations); 3) legal requirements; 4) legal institutions implementing the legal policy of the state; 5) judicial and other legal practice; 6) the mechanism of legal regulation; 6) the implementation process (including acts of application and interpretation); 8) rights, freedoms, and obligations of citizens (law in a subjective sense); 9) legal activity; 10) systems of legal relations formed in society; 11) law and order; 12) legal ideology (justice, legal doctrines, theories, legal culture, etc.); 13) subjects of law (individual and collective); 14) systematic links that ensure the unity, integrity, and stability of the system; 15) other legal phenomena (legal liability, legal personality, legal status, regime, guarantees, legitimate interests, etc.)"3.

Along with the above-mentioned, there is a scientific position according to which "the legal system consists of the following components: 1) institutional - subjective composition (subjects of law) as a system-forming factor of the whole legal system; 2) normative (regulatory) - legal norms and principles governing the relations between the subjects of law, objectified and systematized in normative legal acts; 3 ) ideological - the legal understanding of each person, society, sense of justice, legal culture, the opportunity to evaluate the legal existence and to choose a possible variant of behavior lawful or unlawful; 4) functional (processual) - law-making, lawenforcement, law-application, legal activity, legal education, legal relations, legal practice; 5) communicative - integrative (aggregate) connections of all subsystems of the legal system of society, which generally determine the effectiveness of legal regulation, legality, law, and order ${ }^{4}$.

The last of these stances of understanding of the legal system is seen as more clearly reflecting the types and interconnections of its components, and therefore taken as a basis in our research. It is within the functional component of the legal system that we can identify the initial features of juridical activity.

However, it should be considered that the notion of juridical activity, which has recently received considerable attention, includes many positions of understanding, both with regard to its nature and its types. These issues make it difficult to develop a unified approach to the definition of juridical activity and to establish its place in the legal system of Ukraine. Juridical activity is identified with legal behavior, legal practice, activity, legal forms of state activity, legal process, legal relations, and other related phenomena.

\footnotetext{
${ }^{3}$ Оніщенко Н. М. Правова система: проблеми теорії / Оніщенко Н М. К.: Ін-т держави і права ім. В. М. Корецького НАН України, 2002. С. 18.

Правові системи сучасності. Глобалізація. Демократизм. Розвиток / В. С. Журавський, О.В.Зайчук, О. Л. Копиленко, Н. М. Оніщенко; за заг. ред. В.С. Журавського. К. : Юрінком Інтер, 2003. С. 57.
} 
Given the diversity of approaches to understanding juridical activity as a legal phenomenon in the context of research objectives, it is advisable to consider the law conditionality of juridical activity.

A characteristic feature of juridical activity as an element of any legal system is the fact, that its formation takes place under the influence of the aggregate of ideological, regulatory, economic and other factors.

In this regard, O.V. Minchenko points out that "juridical activity and law act as two sides of the existence of legal reality - theory (doctrine) and practice. The law defines the basic parameters of legal activity - functions, purpose, tasks, as well as the main objects of influence. Thus, in their relation law and juridical activity interact as cause and effect"5.

Juridical activity as a complex and multifunctional legal phenomenon can be studied and defined in different contexts or systems of "coordinates" of scientific research. The analysis of approaches to the interpretation of legal activity in the scientific literature ${ }^{6}$ allows to distinguish the main of them:

- juridical activity as a type of social activity in which it is considered in comparison with other types of social activity - such as economic activity, political activity, pedagogical activity, etc., but juridical activity is identical to legal activity since it can be performed by any subject of law as well as economic activity is carried out not only by economists and political activity not only by politicians;

- juridical activity as a type of legal activity, within which the activity of lawyers is already distinguished, unlike in other types of legal activity, that can be carried out and is carried out by "non-lawyers", but the understanding of juridical activity is usually limited to its legal properties, and to some extent, these properties are lost as a form of social activity (that is, social characteristics that are legal but not reducible to them ${ }^{7}$;

- juridical activity as a legal practice. The limitations of such a scientific analysis lie, first, in its orientation solely to legal practical activity, and thus its removal beyond the scope of the study of juridical scientific and juridical educational activity, and, secondly, its identification with legal practical activity $^{8}$

${ }^{5}$ Мінченко О. В. Особливості здійснення юридичної діяльності в умовах германської правової сім'ї. С. 67.

${ }^{6}$ Жалинский А. Э. Профессиональная деятельность юриста. Введение в специальность. Учебное пособие / А. Э. Жалинский. М. : Издательство БЕК, 1997. С. 6.

${ }^{7}$ Оніщенко Н. М. Правова система: проблеми теорії: Монографія / Н. М. Оніщенко. К. : Ін-т держави і права ім. В. М. Корецького НАН України, 2002. С. 71.

8 Леушин В. И. Соотношение правовой практики и юридической деятельности / В. И. Леушин // Юридическая деятельность: сущность, структура, виды: Сб. науч. тр. Ярославль : Яр. ГУ, 1989. С. 47. 
- juridical activity as an element of the legal system. At the same time, attention is paid to its systematicity, place, role, purpose in the legal system, relations with other elements of the legal system, etc. However, this approach, distinguishing the systematicity of legal reality and the juridical activity itself as the dominant of the scientific search, still reduces juridical activity to legal activity ${ }^{9}$;

- juridical activity as a type of professional activity, the peculiarity of which is its implementation on a professional basis in the legal sphere of public life.

Such an aspect of the study on juridical activity makes it possible to consider it as certain integrity in the unity of social and legal properties ${ }^{10}$.

Thus, pluralism of scientific approaches to the definition of the features of juridical activity, unlike monism (one-dimensionality), provides the comprehensiveness of the study, but the most appropriate for use in this research is the interpretation of juridical activity as a professional activity in the field of law or professional legal activity of lawyers since it is the professionalism of juridical activity that allows to consider it in the unity of social and legal features of a particular profession, therefore, as an element of not only legal, but also economic, political, cultural, social, state, non-state (civil society) and other spheres of public life, or the activity of lawyers as professional legal scholars (practitioners, scientists, educators) in their social properties, that is, in a comprehensive way.

In his turn, D.O. Tikhomirov, analyzing approaches to understanding the juridical activity, notes that "on the basis of those basic provisions concerning juridical activity as a type of social activity, which reflects its general and peculiar properties in relation to social activity and its other types, we should distinguish the following characteristics:

- social activity is carried out in society, and social phenomena are its conditions, forms, means, purpose, results, etc.;

- social activity emerges, exists and evolves in society and is to meet relevant needs;

- the main components of social activity are subjects, objects, subjective and objective parties, or subject - object - purpose - forms, methods, means the result and the actual process of activity;

- by the criterion of spheres of social life, it is divided into economic, political, social (in the narrow sense), spiritual, as well as state and non-state

\footnotetext{
${ }^{9}$ Оніщенко Н. М. Правова система: проблеми теорії: Монографія / Н. М. Оніщенко. К. : Ін-т держави і права ім. В. М. Корецького НАН України, 2002. С. 124.

${ }^{10}$ Гусарєв С. Д. Юридична діяльність: методологічні та теоретичні аспекти: автореф. дис. на здобуття наук. ступеня д-ра юрид. наук: спец. 12.00.01 “Теорія та історія держави і права; історія політичних і правових вчень” / С. Д. Гусарєв. К., 2007. С. 15.
} 
(public), legal and non-legal; by the levels of existence of its subjects activity of society, social collective, individual; by professional implementation - professional and non-professional"11.

In his time, V.M. Kartashov, understood juridical activity as "such mediated professional, labor, the state-power activity of competent bodies in making legal decisions, aimed for performing public functions and tasks (creation of laws, administration of justice, the concretization of law, etc.) and satisfaction of social, group and individual interests ${ }^{12}$. This position, on the one hand, reflects a close relationship with the state, juridical activity is the prerogative of state bodies, so the basic properties of state sovereignty are manifested in this activity, and on the other hand, it significantly reduces the importance of its non-state forms as institutions of civil society.

The work of V.I. Leushin is a certain development of the ideas of V.M. Kartashov. Analyzing juridical activity, Leushin refers to its subjects legislators, competent authorities and their officials who make lawenforcement decisions; bearers of subjective rights and responsibilities, and equates juridical activity with legal practice, legal activity, although puts emphasis on its professional character ${ }^{13}$.

Similar approaches to distinguishing the properties of juridical activity have been applied in the works of other authors, and therefore its peculiar features - legality and professionalism, unity of juridical practical, scientific and educational activity - have remained unaddressed. At the same time, the necessity of this is emphasized by N.M. Onishchenko, who underlines the importance of the conditions of carrying out the professional juridical activity: social environment, legal elements, a system of resource, personnel, information, technical conditions, financial support, and others ${ }^{14}$. O.E. Zhalinsky singles out professionalism as a basic feature of juridical activity ${ }^{15}$.

O.F. Skakun is also prone to this approach considering it necessary to take into account the features of legal practical, scientific or educational activities and their interaction. According to the opinion of O.F. Skakun, juridical

11 Тихомиров Д. О. Юридична діяльність в англо-американській правовій сім’ї (теоретико-правові аспекти). С. 44.

${ }_{12}$ Карташов В. Н. Юридическая деятельность: понятие, структура, ценность. Саратов: Изд-во Саратовского ун-та, 1989. С. 78.

13 Леушин В. И. Юридическая практика в социалистическом обществе: (Гносеологический и специально-юридический аспект): Автореф. дис... д-ра юрид. наук : 12.00 .01 / Свердловск. юрид. ин-т им. Р. А. Руденко. Свердловск, 1990. С. 22.

14 Жалинский А.Э. Профессиональная деятельность юриста. Введение в специальность. Учебное пособие / А. Э. Жалинский. М. : Издательство БЕК, 1997. С. 3.

15 Жалинский А. Э. Профессиональная деятельность юриста. Введение в специальность. Учебное пособие / А. Э. Жалинский. М. : Издательство БЕК, 1997. С. 3. 
activity should be seen as a juridical practice that embraces all areas of activity of lawyers, as legal scholars and is a key element of the content of juridical practice. The author concludes that, in addition to direct juridical practice, the activity of a lawyer also lies in scientific and educational forms. Moreover, the cited work convincingly substantiates the possibility and necessity of interaction of these forms of juridical activity ${ }^{16}$.

In this context, it is necessary to mention the contemporary and comprehensive study of juridical activity carried out by S.D. Gusarev. Summarizing the various positions on the understanding of the nature of juridical activity, the scientist distinguishes its following features:

- it is social in its content and is carried out in the field of law as a legal activity aimed at organizing the activities of other subjects of law, and its purpose is to regulate and harmonize social relations;

- unlike other types of legal activity, juridical activity is characterized, first of all, by professionalism and legality, as its peculiar property, and is carried out by professional lawyers who have the relevant knowledge, skills and abilities;

- the primary classification of legal activity is its division into juridical practical, juridical scientific and juridical educational activities. Other features of juridical activity in this context include the usage of legal and non-legal means, its legal regulation, procedurality and so forth ${ }^{17}$.

In the scope of our research study, the scientific position of S.D. Gusarev is supported and taken as a basis concerning that juridical practice should be considered as a form of legal activity.

S.D. Gusarev notes that "legal activity is proposed to be understood as a type of social activity carried out by legal entities with the use of legal means and with the aim of obtaining a legal result, which contributes to the creation of law, its development and materialization in the process of functioning of public relations" 18 .

In his turn, S.D. Gusarev defines juridical activity as "a kind of legal activity carried out in the field of law by expert lawyers in order to obtain a legal result, meet the legitimate needs and interests of social entities in accordance with the requirements of law"19.

${ }^{16}$ Скакун О. Ф. Правова система України на правовій карті світу / Наукові доповіді інституту державного будівництва та місцевого самоврядування Академії правових наук України. Доповідь № 1. Х.: Еспада, 2004. С.62.

17 Гусарєв С.Д. Юридична діяльність: методологічні та теоретичні аспекти / С. Д. Гусарєв. К. : Знання, 2005. С.35.

${ }_{18}$ Гусарєв С. Д. Правова діяльність в структурі соціальної діяльності // Украӥнське право. 2005. № 1. С. 41

${ }^{19}$ Гусарєв С. Д. Юридична деонтологія (Основи юридичної діяльності): навч.посіб. / С. Д. Гусарєв, О. Д. Тихомиров. К. : Знання, 2005. С. 305. 
Analyzing the above-mentioned provisions, we can state that juridical activity is an important component of the functional block of the legal system. At the same time, there is no doubt that juridical activity is a special type of legal activity within the framework of social activity.

When determining the essential characteristics of juridical activity, its features should be taken into account. According to S.D. Gusarev and O.D. Tikhomirov's juridical activities are characterized by the following features: carried out in the field of law; performed by lawyers; aimed at organizing the activities of other entities; the purpose of juridical activity is to regulate and harmonize public relations; use of both legal and non-legal means; legal regulation of the results of juridical activity; availability of specific forms of implementation: practical, scientific and educational ${ }^{20}$.

The study of these features gives us the opportunity to discover the sociolegal nature of juridical activity and to come closer to understanding its first element, which, in our opinion, is a juridical algorithm.

"Legal activity is carried out in the field of law. The existence of law implies the presence of juridical activity, which ensures the functioning of the law, its effect. In the case of absence of legal norms and law in general, juridical work ceases to be so because it loses its object of influence and its basic toolkit. The sphere of law is all the structural levels and types of social relations where law actually exercises its influence. These are the various spheres of social life, the various situations in which people are guided by the provisions of legal acts to obtain a positive result. Even in such specific spheres of social life as the sphere of religious activity, the sphere of activity of public associations, law also has its influence, though in a somewhat indirect form" 21 .

"Legal activity is carried out by lawyers. This means that legal experts are employed in the field of juridical activity - professionals who have specialized legal knowledge, relevant work skills, and perform qualified legally sighnificant actions that determine the content of their work.

The complexity of situations that are solved by lawyers, the higher standarts of the legal procedure, the peculiarities of formal abstract thinking and terminology of legal communication imply that juridical work should be performed only by specially trained experts. If we analyze the legislation of Ukraine governing the activities of prosecuting authorities, courts, bar and some other bodies and institutions engaged in juridical activity, one of the

20 Гусарєв С. Д., Тихомиров О.Д. Юридична деонтологія (Основи юридичної діяльності): Навч. пос. К.: Знання, 2005. С. 37.

21 Гусарєв С. Д., Тихомиров О.Д. Юридична деонтологія (Основи юридичної діяльності): Навч. пос. К.: Знання, 2005. С. 38. 
requirements for candidates for the post is to have higher legal education. And for the lawyer's activities, for example, there is a requirement to pass the qualification examination, which is taken by a highly competent commission.

There are also relevant qualification commissions in the courts, which periodically check the level of professionalism of their employees. Additional requirements for applicants are proposed for the occupation of particularly responsible positions in legal institutions, which demand a special level of professionalism and considerable experience of legal practice"22.

"Juridical activity is aimed at organizing the activities of other legal entities. It is well known that law in relation to all its subjects exerts a formally equal influence, which is conditioned by the formal equality of the subjects of law in terms of the force of legal orders. However, despite this, a special group of entities stands out, which, in addition to fulfilling their status obligations, must determine the legal position of others, monitor the quality of their implementation of legal norms, assist them in the exercising of subjective rights and legal obligations, to create the right conditions to ensure a high level of implementation of legal rules. With their activities, lawyers assist in the preparation of laws and regulations that govern the life of society. On the basis of legal acts, individuals and legal entities request assistance of lawyers in solving specific situations. Publication of a law enforcement act of regulatory or protective character is one of the key examples of organizational and legal influence" ${ }^{, 23}$.

The purpose of juridical activity is regulation and harmonization of public relations. Law, as we know, establishes certain limits of the possibilities of the person, which cannot be surpassed, because as the boundary of anotherperson is violated, there is an interference with the sphere of rights of another subject.

The tasks that are solved in the course of juridical activity are generally to establish the limits of a possible behavior of the subject, to represent the client's interest, to fill the subjective possibilities with content, to protect the one's sphere from the unlawful interference of other subjects and to oblige the guilty ones to restoring a trespassed border" 24 .

"In the course of juridical activity, both legal and non-legal means are used. In the field of law it is impossible to do without such means, which are in one way or another connected with the law and act as the basic tool in the exercise of the lawyers' powers. Such means are the legal norms, legal

22 Гусарєв С. Д., Тихомиров О. Д. Юридична деонтологія (Основи юридичної діяльності): Навч. пос. К.: Знання, 2005. С. 38.

23 Гусарєв С.Д., Тихомиров О.Д. Юридична деонтологія (Основи юридичної діяльності): Навч. пос. К.: Знання, 2005. С. 39.

24 Гусарєв С.Д., Тихомиров О.Д. Юридична деонтологія (Основи юридичної діяльності): Навч. пос. К.: Знання, 2005. С. 40. 
relations, rights and obligations of legally significant documents and actions, individual legal instructions, orders, legal consciousness, acts of implementation of the law, etc. They are all derivative forms of law are legal phenomena. However, they have to function in different spheres of social life and in interaction with non-legal phenomena. The latter play the role of ancillary or subsidiary means used in the practical activity of lawyers and facilitate to increase their efficiency. Therefore, characterizing legal activity, one should speak of a combination of legal and non-legal means of exercising their powers. For example, along with drawing up a protocol on an administrative offense or issuing a decree recognizing a suspect as a party to the process, the rights and obligations, the nature of the guilt, the unlawful acts and the possible negative consequences are explained"25.

"Legal regulation of juridical activity. Law itself is a very powerful tool, which is explained by the possibility of using state-government coercion, the existence of an appropriate system of guarantees. Applying the legal norm to other persons is a form of exercise of power. Legal actions of lawyers can have serious consequences for other entities. Therefore, the activity of lawyers is well regulated by the legal norms, although the regulatory role of other social norms (norms of morality, corporate norms) can be mentioned.

The existence of a coherent system of organic laws governing the activities of the court, prosecutor's office, bar, police, notary, as well as the existence of a system of procedural laws and norms testify to the orderliness of the legal procedure. Each competence of an official, a legal institution is exercised in a certain form, according to a certain procedure and within a specified term. But a clear regulation of activity demands knowledge of its requirements not only by legal experts, but also by all other persons whose cases are the subject of consideration. Failure to comply with the procedure, violation of the terms of action can have adverse consequences, including in the form of legal liability"26.

"Juridical activity is carried out in the form of practical, scientific and educational activity. Each of these forms has its own peculiarities of purpose, content, means of implementation, etc. and takes place in a specific social environment covered by the concept of the sphere. In this triad, the practice of lawyers is a leading form, and educational and scientific practice appear to be additional or specific forms. Juridical educational and juridical scientific activities are equal elements in the system, and each performs its own

25 Гусарєв С. Д., Тихомиров О. Д. Юридична деонтологія (Основи юридичної діяльності): Навч. пос. К.: Знання, 2005. С. 40.

26 Гусарєв С. Д., Тихомиров О. Д. Юридична деонтологія (Основи юридичної діяльності): Навч. пос. К.: Знання, 2005. С. 41. 
function, which makes a harmonious combination and interaction of elements in the system" 27 .

In our opinion, in addition to these features of juridical activity, the following should be distinguished: juridical activity should be carried out in accordance with legal technologies; procedural and processual form of juridical activity; public and private levels of juridical activity; specialized logistical support of juridical activity.

Conformity of the performed juridical activity to legal technologies, in our opinion, is one of its most important features because it reflects the availability of knowledge regarding the rules, methods and means of organizing and conducting juridical activity.

Procedural-processual form characterizes the external form of manifestation of juridical activity. Juridical activity is always active, aimed at achieving a legal result, carried out in a certain legal order socially significant activity. The organization and the sequence of its implementation meets the requirements of the processual form and is carried out within the juridical process and procedures.

Public and private levels of juridical activity reflect not only the specific nature of its organization, but also indicate the presence of different, by their status, subjects of its implementation, from public servants to lawyers.

The feature of specialized logistical support of juridical activity is related, first of all, to the organization of practical juridical activity, but it does not exclude the need for financing of scientific and pedagogical juridical activity. Availability of the logistic, its systematic financing is the key to high-quality and effective juridical activity.

\section{Juridical algorithms and their place in the field of juridical activity.}

Having determined the nature of juridical activity, its nature and features, it becomes possible to characterize the place of juridical algorithms in the field of juridical activity.

Social regulators in the process of normative generalization of social relations are not only a form and the result of such generalization, but also a means of further ordering influence on the social system.

There is no doubt that social regulation can only happen if it is clearly defined who and in what order should perform certain actions or refrain from their implementation. Given the above-mentioned provisions and the nature of the juridical algorithm, it is possible to classify juridical algorithms according to the following criteria:

27 Гусарєв С. Д., Тихомиров О. Д. Юридична деонтологія (Основи юридичної діяльності): Навч. пос. К.: Знання, 2005. С. 41. 
According to the level of legal regulation: a) general juridical algorithms the provisions contained in the laws, for example, in Article 655 of the Civil Code of Ukraine states that under the contract of sale one party (seller) transfers or undertakes to transfer the property (goods) to the other party (the buyer), and the buyer accepts or undertakes to accept the property (goods) and to pay for it a certain sum of money; b) special juridical algorithms - the provisions contained in law-enforcing or enforcement acts, for example, in the Resolution of the Malinovsky District Court of Odessa on filing a case № 521/22090/14-c from 18.12.2014 the following juridical algorithm is indicated: Defendant is to file written objections to the claim, with reference to the evidence on which they are based ${ }^{28}$;

According to the form of legal activity of the subjects of law: a) juridical algorithms that are implemented through the action, for example, in paragraph 49.3 of Article 49 of the Tax Code of Ukraine it is stated that the tax return is submitted personally by the taxpayer or an authorized person $^{29}$; b) juridical algorithms that are put into practice through legally significant inaction, for example, Article 11 of the Criminal Code of Ukraine states that a crime is a socially dangerous action (act or omission) provided for in this Code and committed by the subject of the crime ${ }^{30}$. Thus, the juridical algorithm of legally significant inaction is the passive behavior of a legal entity to commit a socially dangerous act;

According to the type of legal norms: a) juridical algorithms that are expressed in substantive legal norms, for example, Article 88 of the Economic Code of Ukraine stipulates that members of a business enterprise have the right: to participate in the management of the affairs of the company in the manner specified in the constituent documents, except in cases provided in this Code and other laws ${ }^{31}$; b) juridical algorithms, which are expressed in procedural legal rules, for example, part 2 of Article 27 of the Civil Procedure Code of Ukraine stipulates that persons involved in a lawsuit are required to submit all their evidence before or during the preliminary court hearing in order to confirm their claims or objections, and if the preliminary court hearing is not conducted - before the trial of the merits ${ }^{32}$;

${ }^{28}$ Єдиний державний реєстр судових рішень. URL: http://www.reyestr.court.gov.ua/ Review/42016052

29 Податковий кодекс України від 21.12.2010 p. URL: http://zakon2.rada.gov.ua/ laws/show/1798-19

30 Кримінальний кодекс України від 05.04.2001 URL: http://zakon2.rada.gov.ua/laws/ show/2341-14

31 Господарський кодекс України від 16.01.2003 p. URL: http://zakon0.rada.gov.ua/ laws/show/436-15/paran720\#n720

32 Цивільний процесуальний кодекс України від 02.12 .2010 p. URL: http://zakon3.rada.gov.ua/laws/show/2755-17/paran1206\#n1206 
According to the nature of manifestation in social activity: a) processual juridical algorithms, for example, in part 1 of Article 314 of the Criminal Procedure Code of Ukraine, it is stated that after receiving an indictment, a request for the use of compulsory measures of medical or educational character or a application for an exemption from liability, not later than five days from the date of its receipt, the court appoints a preparatory hearing and summons the participants of the court proceeding ${ }^{33}$; b) juridical algorithms related to the process of procedures, for example, the Law of Ukraine "On Elections of People's Deputies of Ukraine" regulates the procedure for the implementation of separate procedures related to the election process (voting, participation in constituent meetings, etc.), so in part 5 of the Article 85 of this law stipulates that the ballot papers are filled by the voter personally in the booth for secret ballot ${ }^{34}$; c) juridical algorithms of independent legal procedures, for example in paragraph 10 of part 2 of Article 25 of the Law of Ukraine "On State Registration of Legal Entities, Individual Entrepreneurs and Public Organizations", it is stated that the Extract from the Unified State Register in paper form is provided with the signature and seals of the state registrar ${ }^{35}$;

According to the form of expression: a) written juridical algorithms - recorded in the texts of written legal acts; b) oral juridical algorithms - expressed in the officially recognized form of algorithms of verbal implementation of legal norms, for example, verbal order, verbal warning, etc.;

c) conjunctive juridical algorithms - expressed in an officially recognized form of acts of non-verbal or symbolic enforcement of legal rules, for example, subparagraph 1 of paragraph 33 of the Traffic Rules ${ }^{36}$ contains a description of a warning road sign, which, after its actual siting, will be a symbolic conjunctive act attributing certain algorithm of the behavior of subject of law.

According to the degree of historical development of the society: a) conscious algorithms that are based on mono-norms and reflect the order of achievement of the expected result through the implementation of interdependent actions by the individual, or through the refraining from their

\footnotetext{
33 Кримінальний процесуальний кодекс України від 13.04.2012 p. URL: http://zakon3.rada.gov.ua/laws/show/4651-17/paran2769\#n2769

34 Закон України "Про вибори народних депутатів України" від 17.01.2011 p. URL: http://zakon2.rada.gov.ua/laws/show/4061-17/paran1047\#n1047

35 Закон України "Про вибори народних депутатів України" від 17.01.2011 p. URL: http://zakon2.rada.gov.ua/laws/show/4061-17/paran1047\#n1047

36 Правила дорожнього руху від $10.10 .2001 \mathrm{p}$, затверджені Постановою КМУ від 10.10.2001 p., за № 1306 URL: http://zakon3.rada.gov.ua/laws/show/1306-2001-\%D0\%BF/ paran930\#n930
} 
implementation; b) juridical algorithms - the sequence of actions of the subject of law regulated by legal acts.

According to the feature of enforcement and the form of the prescription: a) rigid - algorithms that have a legally binding form; b) mild algorithms that are advisory.

Respectively, regardless of the nature (sequence) of the execution of legal orders, whether it is an action or an inaction (as in the case of the prohibition algorithm), the basis of such implementation is a legal algorithm (a sequence of actions regulated by a legal act).

\section{CONCLUSIONS}

The content and form of juridical activity is expressed in legal acts. The activity of lawyers and many other entities, including those with a competent legal awareness, is to create, effectively use or enforce legal acts.

Legal acts are an external expression and their legal composition and legal technologies are the starting points of the content of the formalization of law. The substantive and formal nature of the legal composition reflects the desired form of legal act, and legal technologies provide the rules, methods and techniques for their creation. The future effectiveness of written legal acts and, accordingly, their impact on the processes of legal regulation of public relations depends on the quality of these provisions.

Creation of legal documents is an integral part of juridical activity, and not only the form, but also certain procedures that transfer the actual relations into the expressed in a written act rule, order, fixation of status, etc. Formalization is a binding element of the law-making process.

It should be noted that in this case, we do not reduce the understanding of law only to the legalistic approach. The idea, the spirit, the principles of law, the, all these axiology notions, along with sociological aspects (conflict and its solution, the so-called "law in life") are also taken into account.

Each of them allows us to get closer to understanding the essence of law, as the most authoritative social regulator in modern society, and to identify issues that arise in the legal field. However, in the modern conditions, the "bare" idea of law (the right of a particular subject / entities) loses effectiveness of its implementation without formal certainty and connection with the state.

\section{SUMMARY}

In summary, it should be noted that juridical activities play an important role in the processes of social relations regulation. This is related not solely to the fact that the results of such activity are the creation of legal acts, but also, it is of great importance for our study, because due to effective juridical 
activity, the rights and freedoms of the subjects of law are embodied and their protection is ensured. The latter indicates that the juridical activity is carried out in accordance with a certain order, which, in our opinion, is clearly stated in the juridical algorithms.

\section{REFERENCES}

1. Господарський кодекс України від 16.01.2003 p. URL: http://zakon0.rada.gov.ua/laws/show/436-15/paran720\#n720

2. Гусарєв С. Д. Юридична деонтологія (Основи юридичної діяльності): навч. посіб. / С. Д. Гусарєв, О. Д. Тихомиров. К. : Знання, $2005.655 \mathrm{c}$.

3. Гусарєв С. Д. Юридична діяльність: методологічні та теоретичні аспекти / С. Д. Гусарєв. К. : Знання, 2005. 375 с.

4. Гусарєв С.Д. Правова діяльність в структурі соціальної діяльності // Украӥнське право. 2005. № 1. С. 41-50.

5. Єдиний державний реєстр судових рішень. URL: http://www.reyestr.court.gov.ua/Review/42016052

6. Жалинский А. Э. Профессиональная деятельность юриста. Введение в специальность. Учебное пособие / А. Э. Жалинский. М. : Издательство БЕК, 1997. 330 с.

7. Зайцев И. М. Понятие и содержание юридического процесса // Теория государства и права. Курс лекций. Под ред Матузова Н. И., Малько А.В. 2-е изд., перераб. и доп. М.: Юристъ, 2001. 442 с.

8. Закон України "Про вибори народних депутатів України" від 17.01.2011p. URL: http://zakon2.rada.gov.ua/laws/show/4061-17/paran 1047\#n1047

9. Карташов В. Н. Юридическая деятельность: понятие, структура, ценность. Саратов: Изд-во Саратовского ун-та, 1989. 218 с.

10. Кримінальний кодекс України від 05.04.2001 URL: http://zakon2.rada.gov.ua/laws/show/2341-14

11. Кримінальний процесуальний кодекс України від 13.04.2012 p. URL: http://zakon3.rada.gov.ua/laws/show/4651-17/paran2769\#n2769

12. Леушин В. И. Соотношение правовой практики и юридической деятельности / В. И. Леушин // Юридическая деятельность: сущность, структура, виды: Сб. науч. тр. Ярославль : Яр. ГУ, 1989. С. 47-53.

13. Леушин В. И. Юридическая практика в социалистическом обществе: (Гносеологический и специально-юридический аспект): Автореф. дис. ... д-ра юрид. наук : 12.00 .01 / Свердловск. юрид. ин-т им. Р. А. Руденко. Свердловск, 1990.35.

14. Мінченко О. В. Особливості здійснення юридичної діяльності в умовах германської правової сім'ї : автореф. дис... канд. юрид. наук: 
12.00.01 / Мінченко Ольга Василівна ; Київський національний ун-т внутрішніх справ. К., 2009. 20 с.

15. Оніщенко Н. М. Правова система: проблеми теорії: Монографія / Н. М. Оніщенко. К. : Ін-т держави і права ім. В. М. Корецького НАН України, 2002. $352 \mathrm{c.}$

16. Податковий кодекс України від 21.12.2010 p. URL: http://zakon2.rada.gov.ua/laws/show/1798-19

17. Правила дорожнього руху від 10.10.2001 p., затверджені Постановою КМУ від 10.10 .2001 p., за № 1306 URL: http://zakon3.rada.gov.ua/laws/show/1306-2001-\%D0\%BF/paran930\#n930

18. Правові системи сучасності. Глобалізація. Демократизм. Розвиток / В. С. Журавський, О. В. Зайчук, О. Л. Копиленко, Н. М. Оніщенко; за заг. ред. В. С. Журавського. К. : Юрінком Інтер, 2003. 296 с.

19. Скакун О. Ф. Правова система України на правовій карті світу / Наукові доповіді інституту державного будівництва та місцевого самоврядування Академії правових наук України. Доповідь № 1. Х.: Еспада, 2004. $96 \mathrm{c.}$

20. Тихомиров Д. О. Юридична діяльність в англо-амеріканській правовій сім’і (теоретико-правові аспекти) : автореф. дис... канд. юрид. наук: 12.00.01 / Тихомиров Денис Олександрович ; Київський національний ун-т внутрішніх справ. К., 2009. 16 с.

21. Цивільний процесуальний кодекс України від 02.12.2010 p. URL: http://zakon3.rada.gov.ua/laws/show/2755-17/paran1206\#n1206

22. Элементарные начала общей теории права. Учебное пособие / Гойман-Калинский И. В., Иванец Г. И., Червонюк В. И.; Под общ. ред.: Червонюк В. И. М.: Колос С, 2003. 544 с.

Information about the author: Manko D. G., Candidate of Juridical Sciences, Associate Professor at the Department of State and Law Disciplines, International Humanitarian University 33, Fontanska Road str., Odessa, 65009, Ukraine 